\title{
Nutritional Status of Children and Adolescents with Type1 Diabetes Mellitus in Basrah
}

\author{
Ban Rahman Dohan ${ }^{1}$, Sawsan Issa Habeeb ${ }^{2 *}$, Abbas Abed Khazaal ${ }^{3}$ \\ 1 Ban Rahman Dohan MD, Misan maternity and children hospital \\ 2 Sawsan Issa Habeeb Professor of pediatrics, Department of Pediatrics, College of Medicine, University of Basrah \\ 3.Abbas Abed Khazaal, Lecturer, Department of Pediatrics, College of Medicine, University of Basrah
}

Received: 24.07.2020

Accepted: 14.03.2021

\begin{abstract}
Growth problems represent an important complication in children and adolescent with Type1 diabetes mellitus and poor metabolic control seems to impact their growth velocity. Aim: to assess the nutritional status in children with type 1 diabetes mellitus, in relation to selected patients' variables.

Methods: a case-control study has been carried out to assess the nutritional status of sixty-one patients with type 1 diabetes mellitus; and eighty-two age and sex matched healthy children as control group; their ages ranged from 3-14 year, from the $1^{\text {st }}$ of October 2016 till 15 th of March 2017.

Results: The mean age of diabetic patients was $(10.3 \pm 3.02)$ years; $(60.66 \%)$ belong to large family size with low education. Diabetic patients significantly belong to families with poor financial support and income in (45.9\%) compared to the control group (26.8\%) (p value $0.02)$, as well as those undernourished diabetic children significantly belongs to families with poor income than those with normal nutritional status $(75 \%, 38 \%)$ respectively. Body mass index was significantly below $5^{\text {th }}$ percentile in diabetic patients than the controls $(19.68 \%, 2.4$ $\%$ ) respectively; P value 0.001 . History of inadequate dietary intake was recorded in $66.67 \%$ of patients; significantly related to undernutrition in diabetics patients than controls ( $\mathrm{P}$ value 0.002). Undernutrition in diabetic children significantly associated with poor

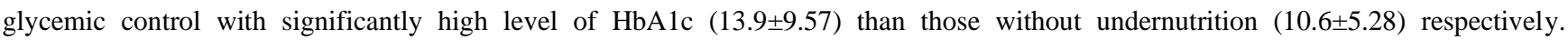
Conclusion: Frequent evaluation of diabetic children is required to overcome the problem of undernutrition in patients with type 1 diabetes mellitus.
\end{abstract}

Keywords: Type1diabetes; Nutritional status; Children.

\section{Corresponding to:}

Sawsan Issa Habeeb, Department of Pediatrics, College of Medicine, University of Basrah, Basrah, Iraq

\section{sawsan19612000@yahoo.com}

\section{Introduction}

Diabetes mellitus is a syndrome of disordered metabolism due to an absolute or relative deficiency of insulin which resulted into inappropriate hyperglycemia. ${ }^{(1)}$ Several studies have suggested growth retardation in children with type 1 diabetes with suboptimal diabetes control and normal growth in children with good metabolic control. (2)

Like other chronic diseases, growth delay may result from combination of pathophysiologic processes such as calorie wasting from hyperglycemia or malabsorption secondary to celiac sprue, chronic acidosis, increased glucocorticoid creation, hypothyroidism and 
delay puberty, the severity is mainly related to glycemic control and to the insulin regimes. ${ }^{(3)}$

The traditional goals of treatment in children and adolescents with diabetes were to balance insulin, diet, and exercise to promote optimal growth and development while minimizing episodes of hypoglycemia and hyperglycemia.

Nevertheless, the association among glycemic control and skeletal growth is unreliable and many kids with seemingly marginal control appear to grow well. Such patients are able to reach normal intracellular nutrition despite apparent hypo-insulinemia. However, that advancement in improving glycemic control in diabetes will improve growth in these children. ${ }^{(5)}$ Factors affecting growth include: gender, genetic, age at diagnosis, diabetes duration, puberty, metabolic control, and status of growth hormone $(\mathrm{GH})$, insulin-like growth factors (IGFs), and IGF binding proteins (IGFBPs) and psychosocial factors. ${ }^{(6)}$

\section{Methods}

A case control study has been carried out to assess the nutritional status of children and adolescent with type1 diabetes mellitus who were registered and followed at Al-Faiha Specialized Diabetes Endocrine and Metabolism Center (FDEMC); Sixty-one patients were enrolled in the study, their ages ranged from 3-14 year; 36 were females and 25 were males. Eighty-two apparently healthy children, were age and sex matched as a control group.

Patients with type 2 diabetes, children with positive serology for celiac disease and hypothyroidism were excluded from the study

A special Questionnaire was designed for the purpose of the study. An informed consent was obtained from the parents for recruitment in the study. All patients underwent general, systemic examination. Anthropometric measurements were assessed and applied to appropriate charts. (7)

Body mass index (BMI) less than $5^{\text {th }}$ percentile has been proposed as a cutoff to define thinness in children. The term "overweight" generally defined as a BMI at or above the $95^{\text {th }}$ percentile of sex-specific BMI-for-age values from the 2000 CDC growth charts. ${ }^{(8)}$

Conventional insulin therapy: define as a twice daily insulin regimens of short and longer acting insulin requirement.

Intensive insulin therapy: which enable insulin dose to be matched to carbohydrate intake in four divided doses. ${ }^{(9,10)}$

Family size is described according to the number of children; those families with $\geq 3$ children regards as large families, and those families with less than 3 children regard as small families. ${ }^{(11)}$ On the other hand family income divided in to: (12)

Low income: below 100,000 ID per capita, Medium: range from 100,000- 250,000 ID per capita,

High: above 250,000 ID per capita

\section{Assessment of dietary requirement:}

Recommended daily allowance and actual intake was calculated according to caloric intake and physical activity of patients by 24 - hours recalls for food intake. ${ }^{(13)}$

The following equation was used:

RDA $=$ Basal metabolic rate $\times$ Physical activity + Thermal effect.

BMR =Ideal body weight $\times 1$ Kcal. $\times 24 \mathrm{hr}$. (in male and $0.95 \mathrm{Kcal}$. in female). 
Hemoglobin A1c (HB A1c) determined by high performance liquid chromatography (HPLC), normal range 4.0-6.0 \%

The Data analyzed using SPSS software version 23 and were expressed by mean \pm Standard Deviation (SD). Comparison was performed by using Chi-Square test and $\mathrm{T}$ test. Logistic regression analysis (Binary Logistic) was also done for the analysis of different marker, by using Odd Ratio (OR) and Confidence Interval (CI). For all test $p$ value was considered as statistically significant if below 0.05 .

\section{Statistical analysis}

All data were analyzed by SPSS (Statistical Package for Social Science - version 15). P value $<0.05$ was considered to be significant.

\section{Results}

The mean age of diabetic patients and control group was $10.3 \pm 3.02,9.3 \pm 2.96$ as well as the frequency of diabetic females and males was $59.02 \%, 40.98 \%$ respectively .

The growth parameter as weight for age (WFA), height for age (HFA), and body mass index (BMI) were significantly below $5^{\text {th }}$ percentile in diabetic children than control group, BMI which is considered as indicator of undernutrition show statistically significant results with $\mathrm{P}$ value (0.001). Table (1)

Diabetic children belong to families with low and medium income were significantly undernourished (P value 0.05 ), on the other hand, history of inadequate dietary intake was recorded in $66.67 \%$ of patients; was significantly related to undernutrition in diabetics patients than controls ( $\mathrm{P}$ value 0.002). Other variables as parents' education and family size show no significant relation to the nutritional status as shown in Table (2)

\begin{tabular}{|c|c|c|c|c|c|c|}
\hline \multirow{2}{*}{$\begin{array}{c}\text { Percent } \\
\text { ile }\end{array}$} & WFA & & HFA & & BMI & \\
\hline & $\begin{array}{c}\text { Cases } \\
\text { No. }(\%) \\
\end{array}$ & $\begin{array}{r}\text { Control } \\
\text { No. }(\%) \\
\end{array}$ & $\begin{array}{c}\text { Cases } \\
\text { No. }(\%) \\
\end{array}$ & $\begin{array}{l}\text { Control } \\
\text { No. }(\%) \\
\end{array}$ & $\begin{array}{c}\text { Cases } \\
\text { No. }(\%) \\
\end{array}$ & $\begin{array}{l}\text { Control } \\
\text { No. }(\%) \\
\end{array}$ \\
\hline$<5^{\text {th }}$ & )$^{17(27.87}$ & $8(9.76)$ & $15(24.59)$ & $3(3.65)$ & $12(19.68$ & $2(2.44)$ \\
\hline $5^{\text {th }}-50^{\text {th }}$ & $24(39.35$ & $34(41.46$ & $32(52.46)$ & $52(63.42)$ & $30(49.18$ & $43(52.44)$ \\
\hline $50^{\text {th }}-95$ & $\begin{array}{l}18(29.51 \\
{ }^{2}\end{array}$ & $\begin{array}{l}35(42.68 \\
)\end{array}$ & $12(19.68)$ & $24(29.28)$ & $\begin{array}{l}17(27.87 \\
\end{array}$ & $31(37.81)$ \\
\hline$>95^{\text {th }}$ & $2(3.27)$ & $5(6.1)$ & $2(3.27)$ & $3(3.65)$ & $2(3.27)$ & $6(7.31)$ \\
\hline Total & $61(100)$ & $82(100)$ & $61(100)$ & $82(100)$ & $61(100)$ & $82(100)$ \\
\hline $\mathrm{P}$ value & 0.017 & & 0.001 & & 0.001 & \\
\hline
\end{tabular}

\begin{tabular}{|c|c|c|c|c|c|c|}
\hline \multirow{2}{*}{\multicolumn{2}{|c|}{ Variables }} & \multicolumn{2}{|c|}{$\begin{array}{l}\text { Diabetic patient } \\
\text { with under } \\
\text { nutrition (No. } \\
\text { 12) }\end{array}$} & \multicolumn{2}{|c|}{$\begin{array}{l}\text { Diabetic } \\
\text { children } \\
\text { without under } \\
\text { nutrition (No. } \\
49 \text { ) }\end{array}$} & \multirow[t]{2}{*}{$P$ value } \\
\hline & & No. & $\%$ & No. & $\%$ & \\
\hline \multirow{4}{*}{$\begin{array}{l}\text { Mothers' } \\
\text { education }\end{array}$} & Illiterate & 1 & 8.3 & 5 & 10.2 & \multirow[t]{4}{*}{0.55} \\
\hline & Primary & 5 & 41.7 & 25 & 51.1 & \\
\hline & Secondary & 5 & 41.7 & 14 & 28.5 & \\
\hline & Academic & 1 & 8.3 & 5 & 10.2 & \\
\hline \multirow{4}{*}{$\begin{array}{l}\text { Fathers' } \\
\text { education }\end{array}$} & Illiterate & 2 & 16.7 & 3 & 6.1 & \multirow[t]{4}{*}{0.56} \\
\hline & Primary & 3 & 25 & 18 & 36.7 & \\
\hline & Secondary & 6 & 50 & 18 & 36.7 & \\
\hline & Academic & 1 & 8.3 & 10 & 20.5 & \\
\hline \multirow[t]{2}{*}{ Family size } & Small & 4 & 33.3 & 20 & 41 & \multirow[t]{2}{*}{0.43} \\
\hline & Large & 8 & 66.7 & 29 & 59 & \\
\hline \multirow{3}{*}{$\begin{array}{l}\text { Family } \\
\text { income }\end{array}$} & Low & 9 & 75 & 19 & 38.7 & \multirow{3}{*}{0.05} \\
\hline & Medium & 2 & 16.7 & 27 & 55.2 & \\
\hline & High & 1 & 8.3 & 3 & 6.1 & \\
\hline \multirow[t]{2}{*}{$\begin{array}{l}\text { Dietary } \\
\text { intake }\end{array}$} & Adequate & 4 & 33.33 & 45 & $\begin{array}{l}91.8 \\
3 \\
\end{array}$ & \multirow[t]{2}{*}{0.002} \\
\hline & $\begin{array}{l}\text { Inadequat } \\
\mathrm{e}\end{array}$ & 8 & 66.67 & 4 & 8.17 & \\
\hline
\end{tabular}

Table (3) shows the duration of treatment in diabetic patients less than one year was significantly related to undernutrition ( $\mathrm{P}$ value 0.003 ), while the age of diagnosis or modality of treatment had no relation to nutritional status of studied patients.

Significantly high level of HbA1c with poor glycemic control in diabetic children with undernutrition aged (10-14 years) ( $\mathrm{P}$ value 0.041). Table (4) 
Nutritional Status of Children and Adolescents with Type1 Diabetes Mellitus in Basrah

\begin{tabular}{|c|c|c|c|c|c|c|}
\hline \multirow{2}{*}{\multicolumn{2}{|c|}{ Variables }} & \multicolumn{2}{|c|}{$\begin{array}{l}\text { Diabetic } \\
\text { patients with } \\
\text { under } \\
\text { nutrition }\end{array}$} & \multicolumn{2}{|c|}{$\begin{array}{l}\text { Diabetic } \\
\text { patients } \\
\text { without under } \\
\text { nutrition }\end{array}$} & \multirow[t]{2}{*}{$\begin{array}{l}P \\
\text { value }\end{array}$} \\
\hline & & No. & $\%$ & No. & $\%$ & \\
\hline \multirow{3}{*}{$\begin{array}{l}\text { Age of } \\
\text { onset } \\
\text { (years) }\end{array}$} & $3-5$ & 2 & 12.5 & 14 & 87.5 & \multirow[t]{3}{*}{0.17} \\
\hline & $>5-10$ & 8 & 21.05 & 30 & 78.95 & \\
\hline & $>10-14$ & 2 & 28.57 & 5 & 71.43 & \\
\hline \multirow{3}{*}{$\begin{array}{l}\text { Duration } \\
\text { of } \\
\text { treatment } \\
\text { (years) }\end{array}$} & $<1$ & 8 & 47.05 & 9 & 52.95 & \multirow[t]{3}{*}{0.003} \\
\hline & $1-5$ & 3 & 7.5 & 37 & 92.5 & \\
\hline & $>5$ & 1 & 25 & 3 & 75 & \\
\hline \multirow{2}{*}{$\begin{array}{l}\text { Modality } \\
\text { of } \\
\text { treatment }\end{array}$} & $\begin{array}{l}\text { Convention } \\
\text { al }\end{array}$ & 7 & 20 & 28 & 80 & \multirow[t]{2}{*}{0.92} \\
\hline & $\begin{array}{l}\text { Intensive } \\
\text { insulin } \\
\text { therapy } \\
\end{array}$ & 5 & 19.23 & 21 & 80.77 & \\
\hline \multicolumn{2}{|l|}{ Total 61} & \multicolumn{2}{|c|}{$12(100)$} & & & $49(100$ \\
\hline
\end{tabular}

\begin{tabular}{|c|c|c|c|c|}
\hline & & $\begin{array}{l}\text { HbAlc level } \\
\text { in diabetics } \\
\text { with under } \\
\text { nutrition }\end{array}$ & $\begin{array}{l}\text { HbA1c level in } \\
\text { diabetics without } \\
\text { under nutrition }\end{array}$ & $\mathrm{P}$ value \\
\hline \multirow{3}{*}{$\begin{array}{l}\text { Age } \\
\text { group } \\
\text { (years) }\end{array}$} & $3-5(3)$ & $6.9 \pm 1.2$ & $6.8 \pm 1.1$ & 0.481 \\
\hline & $\begin{array}{l}>5-10 \\
(25)\end{array}$ & $10.7 \pm 2.8$ & $10.3 \pm 2.07$ & 0.7 \\
\hline & $\begin{array}{l}>10- \\
14(33)\end{array}$ & $13.9 \pm 9.57$ & $10.6 \pm 5.28$ & 0.041 \\
\hline
\end{tabular}

logistic regression analysis of selected variables was studied in Table (5); it reveals that undernutrition in diabetic children are significantly related to their age, duration of treatment, poor dietary intake and low family income.

\begin{tabular}{|l|l|l|l|l|}
\hline \multicolumn{4}{|c|}{ Table (6) Predictors of Undernutrition in T1DM patients } \\
\hline \multirow{2}{*}{ Variables } & \multirow{2}{*}{$\begin{array}{c}\text { Odd } \\
\text { ratio }\end{array}$} & \multicolumn{2}{|c|}{$\begin{array}{c}\text { Confidence } \\
\text { interval }\end{array}$} & \multirow{2}{*}{ P value } \\
\cline { 3 - 4 } & & Lower & \multicolumn{1}{|c|}{ Upper } & \\
\hline Age & 0.169 & 0.029 & 0.99 & 0.049 \\
\hline Dietary intake & 0.01 & 0.0012 & 1.1 & 0.002 \\
\hline $\begin{array}{l}\text { Modality of } \\
\text { treatment }\end{array}$ & 6 & 1.2 & 28.6 & 0.92 \\
\hline $\begin{array}{l}\text { Duration of } \\
\text { treatment }\end{array}$ & 2.6 & 0.22 & 31.06 & 0.003 \\
\hline Family income & 1.7 & 0.26 & 12.02 & 0.05 \\
\hline
\end{tabular}

\section{Discussion}

Growth is a complex process influenced by many genetic and environmental factors and abnormal growth secondary to chronic metabolic status like diabetes mellitus.

The growth parameters (WFA, HFA, BMI) of diabetic children were significantly lower than that of control group, undernutrition in diabetic children was 19.7\%; which is in consistent to Vaman et al study in India ${ }^{(14)}$ and Stipancić $G$ et al in Croatia. ${ }^{(15)}$

In contrast to Economos et al ${ }^{(16)}$ who reported that approximately one-third of children in the USA are either overweight or obese possible because malnutrition particularly undernutrition has remained a major health challenge in children in low-income developing countries and more in those with chronic diseases.

The American Diabetes Association released a position statement emphasizing the importance of psychosocial care for people with diabetes. ${ }^{(18)}$ Socioeconomic status of studied patients reveals that poor financial support and poor living conditions particularly with regard to access to food and health care is an important factor determine their nutritional status; that's against Manal et al study who reported that $60 \%$ of diabetic patients belong to high income families. (17)

Higher frequency of inadequate dietary intake was reported in diabetic children compared with control group, this is mainly due to improper food intake and dietary restriction, similar result reported from Mona et al study who showed the effect of nutritional intake on health status. ${ }^{(19)}$ The etiology of disorders of eating behavior in diabetes seems to be multifactorial. Behaviors 
and attitudes that are important components of diabetes management, such as dietary restraint and counting carbohydrates, may place an unhealthy emphasis on food intake that results in dysregulated eating pattern. ${ }^{(20)}$ Undernutrition in diabetic patients are more common in first year of diagnosis which indicate that nutritional status deterioration may begin at early stage of diagnosis and improve with beginning of treatment and improvement of glycemic control. Some studies have shown that the first year afterT1D diagnosis is essential to the acceptance and adaptation of the patients and their relatives to the disease. These studies also have described that those patients who adapt more quickly have a better prognosis. ${ }^{(21)}$

In this study the modality of treatment whether conventional or intensive insulin therapy didn't significantly influence the nutritional status of diabetic children, in contrast to Vaman et al ${ }^{(14)}$, who concluded that undernutrition is less frequent in diabetic patients receiving intensive insulin therapy than those who receive conventional therapy.

$\mathrm{HbA1c}$ which is a reliable index of long-term glycemic control in diabetic patients and high values of HbA1c are indicative of persistent hyperglycemia, which is a common cause for undernutrition in diabetic patients was more noticeable in the age group ( $>10-14$ years).

Similar studies have documented that poor metabolic control was associated with growth impairment in diabetic children. (22) In fact, similarly to what documented in healthy adolescents, also in subjects with T1D puberty is associated with a reduction in insulin sensitivity, which might negatively influence growth and height gain. (23)
There are conflicting literatures on anthropometric parameters in children with diabetes, while it is generally agreed that there is impairment of anthropometric parameters in diabetic children, some studies report that these are related to metabolic control while others have reported that differences in growth parameters cannot be attributed to metabolic control alone. This finding suggest other possible mechanisms for growth failure in children with diabetes mellitus and further investigations are needed to understanding growth impairment in diabetic children $^{(24)}$

\section{Conclusion}

undernutrition is a considerable problem in children with type 1 diabetes mellitus, and growth evaluation need to be considered as one of the main tasks in the regular follow up of these populations.

Conflict of interest: The authors declare no conflict of interest.

Financial Support: None declared.

\section{References}

1. Masharani U, Michael S. Pancreatic Hormones and Diabetes Mellitus.in: Daived G, ShobackD(eds). Greenspan's basic \& clinical endocrinology; $9^{\text {th }}$ ed. United States, McGraw-Hill. 2011; 17; 587.

2. Baruah MP, Ammini AC, Khurana ML. Demographic, breast-feeding, and nutritional trends among children with type 1 diabetes mellitus. Indian $\mathbf{J}$ Endocrinol Metab. 2011; 15(1): 38- 42. 
3. Philippe F, Tulsidas M, Cohen P, Ron G. Disorders of growth hormone/ insulinlike growth factor secretion and action. In: Mark A. Sperling (eds), pediatric endocrinology 4th ed. United States, Elsever.2014; 10; 331

4. Kristin A, William V. Diabetes Mellitus in Children and Adolescents In: Radovick S, Margaret H, P. Michael Conn, pediatric endocrinology a practical clinical guide, 2nd Ed. USA New York, Springer. 2013; 28; 509

5. American Diabetes Association. Diagnosis and classification of diabetes mellitus. Diabetes Care. 2012; 35(Suppl 1): S64-S71.

6. Mark A. Atkinson.Type1 Diabetes Mellitus. In: Melmed S, S. PolonskyK, Williams(eds). Textbook of endocrinology, 13th ed. Philadelphia, Elsevier. 2016; 1466-7

7. Berkley J, Mwangi I, Griffiths K, Ahmed I, Mithwani S, English M,Newton C, Maitland K. Assessment of severe malnutrition among hospitalized children in rural Kenya. JAMA 2005; 294:591596.

8. Center for Disease Control and Prevention 2000 Growth Charts for the United State: National Center for Health statistics version -clinical version 2000.

9. Ounse M. Abd-Alrazak, Batool a Ghalib. Growth indices among children and adolescents with type 1 diabetes in Bagdad. J Fac MED Bagdad 2014; 56(3).2014.

10. Borchers AT, uiboR, Gershwan ME. The geoepidemiology of type1 diabetes. autoimmunity; 2010; 9:355-365.
11. William $\mathrm{H}$, Donald S,Richard $\mathrm{R}$ .NAPRTCS 2005 CKD education ;131D;13-6.

12. Shakir M, Jasim N. Quality of life and its determinants in people with epilepsy in Basra, Iraq. Sultan Qaboos University, 2012, vol.12 (4): 449-457.

13. Donna S. and Robert MK. Nutritional challenges in pediatric CKD in Denis. Geary,Franz Schaefer. Comprehensive pediatric nephrology; $1 \mathrm{P}$ St Ped. Philadelphia, Elsevier Mosby .2008; 745.

14. Vaman V Khadilar, Lavanyas. parthasarathy. Growth status of children and adolescent with type 1 diabetes mellitus. Indian $\mathrm{j}$ endocrinol metab .2013;17(6):1057-1060.

15. Stipancić G, La Grasta Sabolić L, Jurcić Z. Growth disorders in children with type 1 diabetes mellitus. Coll Antropol. 2006;30(2):297-304.

16. Economos CD, Bakun PJ, Herzog JB, Dolan PR, Lynskey VM. Children's perceptions of weight, obesity, nutrition, physical activity and related health and socio-behavioral factors. Public Health Nutrition. 2012 (16) :1-9

17. Manal A. hasseanein. Evaluation of nutrition and health status among children with diabetic; life science journal 2014; 11(2)

18. Young-Hyman D, de Groot M, HillBriggs F, Gonzalez JS, Hood K, Psychosocial care for people with diabetes: a position statement of the American Diabetes Association. Diabetes Care 2016;39: 2126-2140

19. Mona E M Naga. Evaluation of nutrition and health status among children with 
diabetes; specific education research journal; 2011;22: 713-730.

20. Angel S.Y. Nip1, Beth A. Reboussin, Dana Dabelea, et al. Disordered Eating Behaviors in Youth and Young Adults with Type 1 or Type 2 Diabetes Receiving Insulin Therapy. Diabetes Care 2019 May; 42(5): 859-866.

21. Guthrie DW, Bartsocas C, Jarosz-Chabot $\mathrm{P}$, Konstantinova M. Psychosocial issues for children and adolescents with diabetes: overview and recommendations. Diabetes Spectr.2003;16:7-12.

22. Nayera E. Hassan, Ahmed El-Kahky, Mona Atteya Hana, et al. Physical
Growth and Body Composition of Controlled Versus Uncontrolled Type 1 Egyptian Diabetic Children. OA Maced J Med Sci. 2014 Dec 15; 2(4):567-572.

23. C. A. Bloch, P. Clemons, and M. A. Sperling, "Puberty decreases insulin sensitivity," Journal of Pediatrics. 1987; 110 (3): 481-7

24. SaydahSH, Fradkin J , Cowie CC . Poor control of risk factors for vascular disease among adults with previously diagnosed diabetes. JAMA 2004 ;291(3): 335- 42. 